\title{
Hypoxic Preconditioning Improves Spatial Cognitive Ability in Mice
}

\author{
Guo Shao a, b, e Ran Zhang ${ }^{d}$ Zhan-Li Wang ${ }^{e}$ Cui-Ying Gao ${ }^{c}$ Xia Huo ${ }^{a}$ \\ Guo-Wei Lub \\ ${ }^{a}$ Central Laboratory, Shantou University Medical College, Shantou, ${ }^{b}$ Institute for Hypoxia Medicine and \\ 'Basic Medical College, Capital Medical University and d Peking Union Medical College, Tsing Hua University, \\ Beijing, and 'Biomedicine Research Center and Basic Medical College, Baotou Medical College, Baotou, China
}

\section{Key Words}

Neural cell adhesion molecule - Long-term potentiation • Hypoxic preconditioning $\cdot$ Mice

\begin{abstract}
Although it has been reported in a lot of studies that hypoxic preconditiong could protect the brain from hypoxic/ischemic injury, it is not clear whether hypoxic preconditioning could affect brain functions such as cognitive ability. This work aims at investigating the effect of hypoxic preconditioning on spatial cognitive ability in mice after acute and repeated hypoxic exposures. The mice were randomly divided into 3 groups: a control group in which mice were not exposed to hypoxia $(\mathrm{H} 0)$ and experimental groups in which mice encountered hypoxia either once $(\mathrm{H} 1)$ or 4 times $(\mathrm{H} 4)$. Neural cell adhesion molecule (NCAM) expression, longterm potentiation (LTP) recording and Morris water maze test were used to measure the animals' cognitive ability. The tolerance time was progressively prolonged as exposure went on. The expression of both NCAM mRNA and NCAM protein as well as the LTP induction rate decreased in group $\mathrm{H} 1$, but recovered to control level in group $\mathrm{H} 4$. The performance of mice in the maze test was improved in $\mathrm{H} 4$ in comparison with that in both $\mathrm{H} 1$ and $\mathrm{H} 0$. These findings may indicate that spatial cognitive ability is improved in adult mice by their hypoxic preconditioning.
\end{abstract}

Copyright $\odot 2008$ S. Karger AG, Base
() 2008 S. Karger AG, Basel

$1424-862 X / 06 / 0156-0314 \$ 23.50 / 0$

Fax +41613061234

E-Mail karger@karger.ch

www.karger.com
Accessible online at:

www.karger.com/nsg

\section{Introduction}

Hypoxia is a common and important problem in both clinic and extreme environments. Medical approaches in counteracting the devastating effects of hypoxia have been limited only to such oxygen supplementation treatments as oxygen inspiration, high-pressure oxygen chamber, transfusion, improvement of cardiovascular function and so on. It is well known that a sublethal ischemic/ hypoxic exposure could improve the tolerance of tissue or cell to a subsequent lethal ischemic/hypoxic insult. This phenomenon is called ischemic/hypoxic preconditioning (I/HPC) and was first observed in the heart and later in gerbil brain $[1,2]$. However, little is known about the mechanisms that occur in the time period between hypoxic preconditioning (HPC) and the formation of tolerance to ischemic/hypoxic injury. But it has been amply and clearly proved that I/HPC has a remarkable effect on neuroprotection under ischemic/hypoxic conditions [3-7].

It has been shown by many reports that hypoxia impairs learning and memory in animals and humans $[8$, 9], and that intermittent hypoxia can also induce cognitive deficits both in children and adults $[10,11]$. In contrast to these reports on impairing cognitive ability, it was also presented that neonatal intermittent hypobaric hypoxia exposure enhanced mouse spatial learning and memory ability and that mild HPC prevented impair-
Guo-Wei Lu

Institute for Hypoxia Medicine

Capital Medical University

100069 Beijing (China)

Tel. +8610 8391 1942, E-Mail gwlu@ccmu.edu.cn 
ment of passive avoidance learning [12, 13]. Further study of the protective effect of HPC against the impairment of learning and memory is thus highly needed.

Our model belongs to whole-body HPC, by which an intrinsic protective potential can be induced within a short period of time [12]. Using this model, we demonstrated that during the development of HPC, the tolerance time of animals in the hypoxic chamber is significantly prolonged; the expression of superoxide dismutase is remarkably increased, but the expression of lipid peroxidase and nitric oxide is decreased; and there are some notable changes of signal transduction molecules such as extracellular signal-regulated protein kinases, protein kinases C [14-22]. It has been proved that superoxide dismutase, nitric oxide, extracellular signal-regulated protein kinases and protein kinases $\mathrm{C}$ all play an important role in learning and memory [23]. So the present study aimed to explore the effects of HPC on cognitive abilities by simultaneously measuring changes in neural cell adhesion molecule (NCAM) expression, long-term potentiation (LTP) recording and Morris water maze test.

\section{Materials and Methods}

\section{Animal Model}

The ICR mice were developed from the Swiss-Webster albino mice and have been used as a model to explore the cognitive ability under hypoxia condition [24]. A total of 90 male adult ICR mice (16.0-22.0 g) were separated into 3 groups randomly and exposed, respectively, to hypoxia for 4 runs (group H4), 1 run (group H1) and 0 runs (group H0). The procedure of hypoxic exposure was performed as previously described $[14,15]$. Briefly, the animals were placed into a $125-\mathrm{ml}$ jar with fresh air and the jar was sealed with a rubber plug. The tolerance limit was judged by the animals' appearing gasping breath phenomenon for each run. The animal was removed from the jar as soon as the first gasping breath appeared and was switched to another fresh air-containing jar of similar volume. This procedure was performed once (group H1) or repeated 4 times (group H4). The time period between the beginning of airtightness and the appearance of the first gasping was termed 'tolerance time' for each run.

\section{RNA Isolation and Semiquantitative Reverse Transcription}

Polymerase Chain Reaction Analysis

Eighteen mice (6 per group) were exposed or not to hypoxia, and total RNA was prepared from mouse (6-8 weeks old) hippocampus using the RNeasy Mini Kit (Qiagen). Total RNA ( $1 \mu \mathrm{g})$ was reverse transcribed with Superscript reverse transcriptase (Invitrogen). The resulting cDNAs $(1 \mu \mathrm{l})$ was subjected to amplification in a total volume of $20 \mu \mathrm{l}$ containing $1 / 10$ volume of a $10 \times$ buffer, $1.5 \mathrm{mmol} / \mathrm{l}$ of $\mathrm{MgCl}_{2}, 0.2 \mathrm{mmol} / \mathrm{l}$ each of dNTP, $1 \mathrm{U}$ Taq polymerase (Takara) and a pair of specific primers $(0.2 \mu \mathrm{mol} / \mathrm{l}$ each). Primers for NCAM and glyceraldehyde phosphate dehydrogenase (GAPDH) were designed by using the Primer Premier 5.0 software and both sequences were obtained from GenBank. GAPDH forward primer: 5'-CCCTTCATTGACCTCAAC-3', reverse primer: 5'-TTCACACCCATCACAAAC-3'; NCAM forward primer: 5'-ACTCCTCTACССТCACCATC-3', reverse primer: 5'-GCCTCGTCGTTTTTATCC-3'. The polymerase chain reaction (PCR) temperature for NCAM was as follows: cycles at $92^{\circ} \mathrm{C}$ for $30 \mathrm{~s}, 53^{\circ} \mathrm{C}$ for $30 \mathrm{~s}$ and $72^{\circ} \mathrm{C}$ for $60 \mathrm{~s}$, total 29 cycles, followed by a final extension period at $72^{\circ} \mathrm{C}$ for $5 \mathrm{~min}$. The PCR temperature for GAPDH was: cycles at $92^{\circ} \mathrm{C}$ for $40 \mathrm{~s}, 50^{\circ} \mathrm{C}$ for $40 \mathrm{~s}$ and $72^{\circ} \mathrm{C}$ for $45 \mathrm{~s}$, total 20 cycles, followed by a final extension period at $72^{\circ} \mathrm{C}$ for $5 \mathrm{~min}$. Nine microliters of the PCR products were separated by $1.0 \%$ agarose gel electrophoresis and stained with ethidium bromide. RT-PCR products were $621 \mathrm{bp}$ for NCAM and $301 \mathrm{bp}$ for GAPDH.

\section{Western Blot Analysis}

Twenty-four mice (8 per group) were exposed or not to hypoxia and the total proteins were extracted from mouse hippocampus according to a previously described protocol [25]. Protein concentrations were determined by the bicinchoninic acid method. Total cell lysate of mouse hippocampus $(80 \mathrm{~g})$ was separated by $8 \%$ SDS/PAGE at $30 \mathrm{~mA}$ for $2.5 \mathrm{~h}$ and then blotted onto a nitrocellulose membrane. The membrane was then incubated for $1 \mathrm{~h}$ in blocking buffer (TBS containing 10\% skimmed milk powder) at room temperature. Next, the membrane was incubated at $4^{\circ} \mathrm{C}$ for $16 \mathrm{~h}$ with a goat anti-NCAM polyclonal antibody (Santa Cruz Biotechnology). Then the membrane was incubated with horseradish peroxidase-labeled secondary antibodies at room temperature for $1 \mathrm{~h}$. After each incubation, the membrane was thoroughly washed with Tween-TBS 3 times. Protein signals were detected by an ECL detection system (Pierce Chemical Company) in which the membrane is exposed to the detection solution for 5 min.

\section{Hippocampal Slice Preparation and LTP Recording}

Hippocampal slices ( $400 \mu \mathrm{m}$ thick) were prepared from adult male ICR mice (6-8 weeks old). Before sacrifice, 3 groups of mice were not exposed to hypoxia, or exposed once or 4 times. After sacrifice, the brain was rapidly removed and placed in ice-cold, oxygenated artificial cerebrospinal fluid (ACSF) for about $1 \mathrm{~min}$. The brain was then bisected, blocked and mounted on the stage of a Vibratome (McIlwain), and transverse hippocampal slices were cut in ice-cold ACSF, as described previously [26]. Normal ACSF ( $\mathrm{pH} 7.2-7.4$ ), containing (in $\mathrm{mM}$ ) $\mathrm{NaCl} 124, \mathrm{KCl} 4.9$, $\mathrm{KH}_{2} \mathrm{PO}_{4} 1.2, \mathrm{CaCl}_{2} 2.5, \mathrm{MgSO}_{4} 2.4, \mathrm{NaHCO}_{3} 25.6$ and glucose 10 , was equilibrated with $95 \% \mathrm{O}_{2}$ and $5 \% \mathrm{CO}_{2}$. Freshly prepared slices were kept in ACSF at room temperature for at least $3 \mathrm{~h}$ before being recorded.

A single hippocampal slice was then transferred to the recording chamber, in which it was held submerged between 2 nylon nets and maintained at $32^{\circ} \mathrm{C}$. The mixed gas flushed constantly on the upper surface of the slice and the warm ACSF $\left(30^{\circ} \mathrm{C}\right)$ flushed under the lower surface in the opposite direction of the gas. Extracellular recordings of field excitatory postsynaptic potentials (fEPSP) and population spikes (PS) were obtained from the pyramidal cell layer of the CA1 region with microelectrodes filled with $4 \mathrm{M} \mathrm{NaCl}$ (resistance 2-10 $\mathrm{M} \Omega$ ) by using an amplifier. The stimulating electrode was placed on the Schaffer 
collateral of CA3. A single test stimulus $(200 \mu \mathrm{s})$ was applied at intervals of $1 \mathrm{~s}$ and the basal stimulus intensity was set at a level when a PS of half to two thirds of the maximum was evoked. The stimulation was delivered at the basal stimulation intensity, and the timing was controlled by Power Lab software (AD Instruments Inc.). The tetanic stimulation was given with a parameter of $100 \mathrm{~Hz}$ and 100 times. When the amplitude of PS (or fEPSP) was increased by more than $20 \%$ after high high-frequency stimulation, the LTP was thought to be successfully induced. Before the induction of LTP, the fEPSP was recorded for $20 \mathrm{~min}$ as the baseline.

\section{Modified Morris Water Maze Test}

The Morris water maze consisted of a circular pool $(1.2 \mathrm{~m}$ in diameter, $0.27 \mathrm{~m}$ deep, with a water temperature of $26^{\circ} \mathrm{C}$ and a water depth of $0.11 \mathrm{~m}$ ). The pool water was made opaque by the addition of $150 \mathrm{ml}$ nontoxic white paint. A glass escape platform $(6 \times 6 \mathrm{~cm})$ was submerged approximately $1.5 \mathrm{~cm}$ below the water surface in a fixed position in the northeast quadrant. The movements of animals were recorded with a video camera and data were analyzed using a tracking program (Ethovision; Noldus). Mice were placed in the water and trained to locate the platform on 5 consecutive days with 4 successive trials per day. A 20-min interval was imposed before the beginning of the next trial. Each trial began from a different start position (north, south, east, west) with the order changed every day in a large and quiet test room, and mice were given external cues (lamp was used) for navigation to the platform. On each trial, animals were placed in the water maze with the head facing the wall of the maze and were allowed a maximum of $120 \mathrm{~s}$ to locate the hidden platform. Mice failing to locate the platform within $120 \mathrm{~s}$ were placed on the platform by the experimenter and allowed to stay there for $30 \mathrm{~s}$ before the next trial was initiated. On day $5,1 \mathrm{~h}$ after the last training trial, all mice were given a 60 -second probe trial in which the platform was removed from the pool to evaluate their spatial memory. Then they were randomly divided into 3 groups (7 per group) and exposed to hypoxia or not. To test the effects of hypoxia, animals were retested in the water maze with the hidden platform moved to a different quadrant (southeast) 24,48 and $72 \mathrm{~h}$ after the last training trial. Except for the change in the position of the escape platform, the procedures during days $6-8$ were similar to those during days $1-5$. The time mice spent in finding the submerged platform (escape latency) and the swim speed were recorded and the mean escape latency was taken as a measure of spatial learning and memory.

\section{Quantification and Statistical Analysis}

The optical density (OD) of bands of PCR products and Western blot was obtained through the Gel-Doc analysis system and analyzed by Bandscan software. The data of RT-PCR were presented as relative abundance and the data of Western blots were presented as OD. All data were analyzed by the SPSS 10.0 software (SPSS Inc.). The mean escape latency to find the platform was assessed by repeated measures analysis of variance. For the tolerance time, the relative abundance of NCAM mRNA, the OD of NCAM protein, LTP and the swim speed in the water maze were analyzed by one-way analysis of variance and the Tukey test. $\mathrm{p}<$ 0.05 was considered to be statistically significant.

\section{Results}

\section{Effect of Acute and Repeated Exposure of Mice to}

Hypoxia on Hypoxic Tolerance Time

The increment of tolerance to hypoxia in each run was approximately in an arithmetic progression. The tolerance time of each run lasted significantly longer and longer as the exposure run increased. The average tolerance times of runs 1, 2, 3 and 4 were $17.2 \pm 2.9,37.4 \pm 5.7,58.5$ \pm 7.3 and $78.7 \pm 7.9 \mathrm{~min}$, respectively (table 1 ), which is in accordance with our previous findings $[14,15]$.

\section{Acute and Repeated Exposure of Mice to Hypoxia on NCAM mRNA Expression in the Hippocampus}

The NCAM mRNA was analyzed by RT-PCR immediately after hypoxic exposures or not exposures. The relative abundance value of NCAM mRNA in each group was calculated by the OD ratio of NCAM to GAPDH. The RT-PCR product of NCAM in group $\mathrm{H} 1$ markedly decreased and in group $\mathrm{H} 4$ it recovered to $\mathrm{H} 0$ level (fig. 1a). The relative abundance value of group H1 (1.05 \pm 0.43$)$ was significantly lower than that of group H0 (1.60 \pm 0.36 ; $\mathrm{p}<0.05)$. However, after repetitive hypoxic exposure, the NCAM value recovered at $\mathrm{mRNA}$ level in group $\mathrm{H} 4$ (1.62 \pm 0.42$)$. A significant difference in the relative quantities of NCAM between groups $\mathrm{H} 1$ and $\mathrm{H} 4$ was detected $(\mathrm{p}<0.05)$, while no difference was shown between groups $\mathrm{H} 0$ and $\mathrm{H} 4$ (fig. 2a).

\section{Acute and Repeated Exposure of Mice to Hypoxia on NCAM Protein Expression in the Hippocampus}

By using a rabbit polyclonal antibody (Santa Cruz Biotechnology), NCAM protein was detected by Western blot in the 3 groups (fig. 1b). As shown in figure $1 \mathrm{~b}$ and table 2 , three bands in each line could be detected and the $180-\mathrm{kDa}$ isoform of NCAM was found to be significantly lower in group $\mathrm{H} 1(23,894.6 \pm 5,653.6)$ in comparison with group H0 $(33,723.4 \pm 1,834.1 ; \mathrm{p}<0.05)$. After repetitive hypoxic exposure, more $180-\mathrm{kDa}$ NCAM was expressed in group $\mathrm{H} 4(40,113.5 \pm 4,580.3)$ than in groups $\mathrm{H} 0$ and $\mathrm{H} 1$ ( $\mathrm{p}<0.05$; fig. 2b). No difference was discerned in the 140 - and $120-\mathrm{kDa}$ isoform of NCAM among the 3 groups.

\section{Acute and Repeated Exposure of Mice to Hypoxia on LTP Induction}

Both PS and fEPSP could hardly be induced in group $\mathrm{H} 1$, but their induction rate in group $\mathrm{H} 4$ almost recovered to the level of group $\mathrm{H} 0$ (fig. 3). The median of percentage of fEPSP amplitude change in hippocampal slices was 

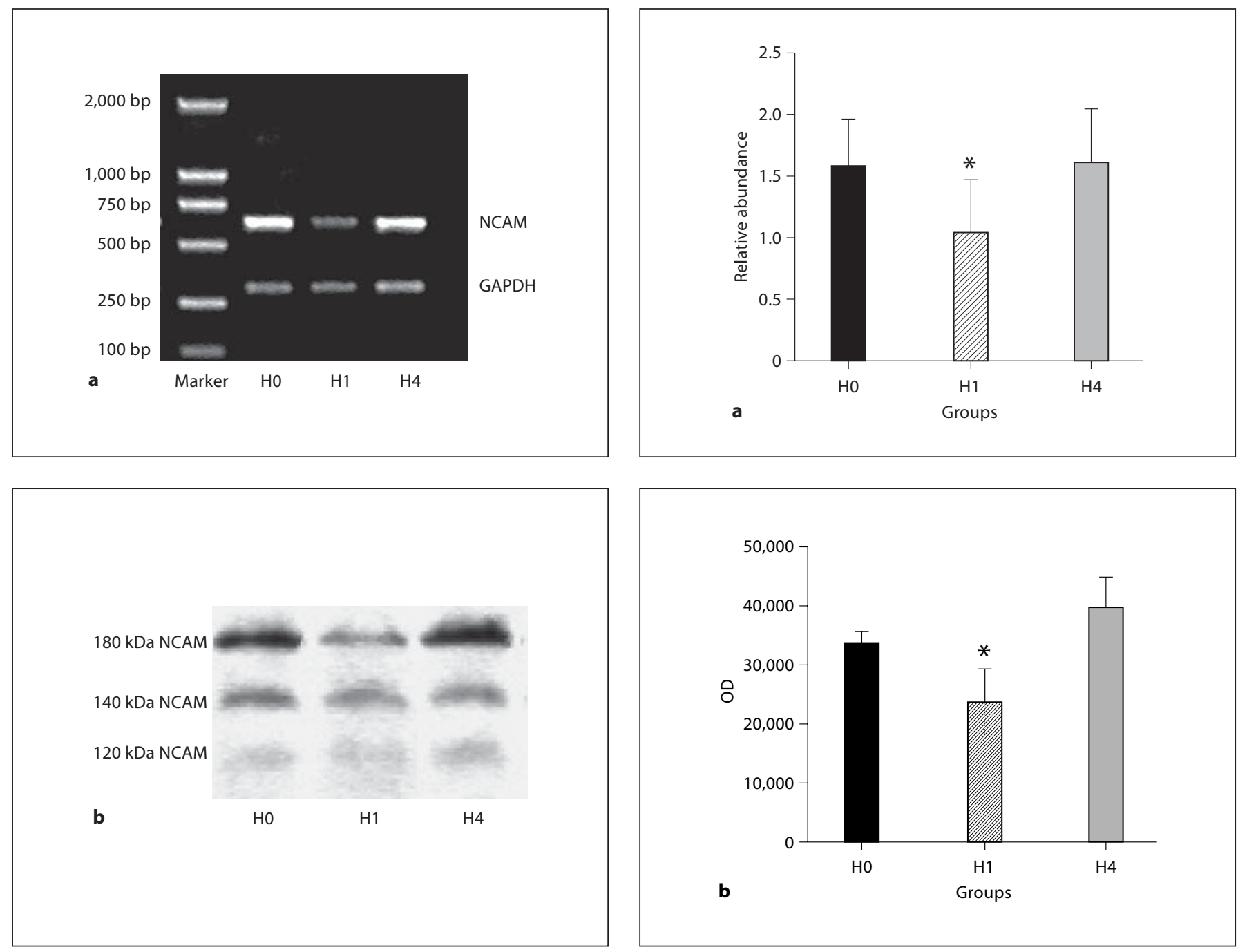

Fig. 1. a Electrophoresis of NCAM and GAPDH RT-PCR products in agarose gel. b Western blotting of NCAM proteins in mouse hippocampus.

Fig. 2. a Ratio of NCAM mRNA to GAPDH mRNA in the H0, H1 and $\mathrm{H} 4$ groups $(\mathrm{n}=6) .{ }^{*} \mathrm{p}<0.05$ vs. groups $\mathrm{H} 0$ and $\mathrm{H} 1$. b Expression of NCAM protein in mouse hippocampus $(n=8) .{ }^{*} \mathrm{p}<0.05$ vs. groups $\mathrm{H} 0$ and $\mathrm{H} 1$.

Table 1. Tolerance time of mice exposed to hypoxia for 1-4 runs/ $\min (\bar{x} \pm s)$

\begin{tabular}{lllll}
\hline & 1 & 2 & 3 & 4 \\
\hline Tolerance time & $17.2 \pm 2.9$ & $37.4 \pm 5.7^{* *}$ & $58.5 \pm 7.3^{* *}$ & $78.7 \pm 7.9^{* *}$ \\
\hline
\end{tabular}

${ }^{* *} \mathrm{p}<0.01$ compared with preceding times $(\mathrm{n}=30)$.

Table 2. Effect of hypoxia preconditioning on expression of $\operatorname{NCAM}(\mathrm{IOD}, \bar{x} \pm s, \mathrm{n}=8$ ) in mouse hippocampus

\begin{tabular}{llll}
\hline & H0 & H1 & H4 \\
\hline $180 \mathrm{kDa}$ & $33,723.4 \pm 1,834.1$ & $23,894.6 \pm 5,653.6^{* *}$ & $40,113.5 \pm 4,580.3^{*++}$ \\
$140 \mathrm{kDa}$ & $25,695.4 \pm 7,176.0$ & $24,079.3 \pm 7,394.6$ & $25,747.5 \pm 8,238.0$ \\
$120 \mathrm{kDa}$ & $17,771.8 \pm 7,198.2$ & $18,188.6 \pm 7,471.7$ & $16,965.4 \pm 7,258.3$ \\
\hline \multicolumn{2}{c}{$\mathrm{p}<0.05 ;{ }^{* *} \mathrm{p}<0.01$ vs. H0; ${ }^{+} \mathrm{p}<0.01$ vs. H1. } & \\
\hline
\end{tabular}

HPC Improves Spatial Cognitive Ability 


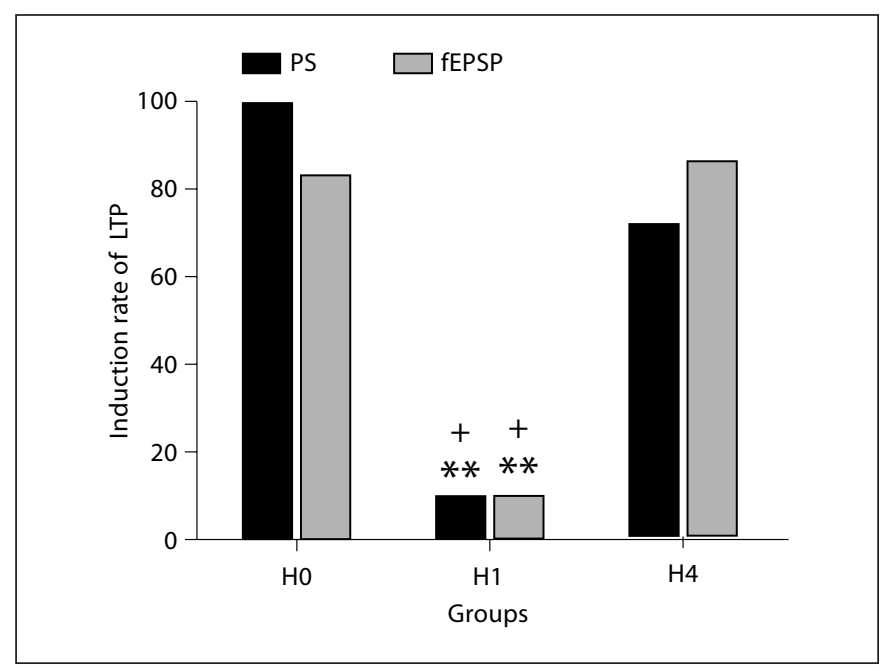

Fig. 3. Probability of LTP induction rate among groups $\mathrm{HO}(\mathrm{n}=$ 6), H1 $(\mathrm{n}=10)$ and $\mathrm{H} 4(\mathrm{n}=7) .{ }^{* *} \mathrm{p}<0.01$ vs. $\mathrm{H} 0 ;{ }^{+} \mathrm{p}<0.05$ vs. $\mathrm{H} 4$.

$61.7,-14.7$ and $32.6 \%$ in groups $\mathrm{H} 0, \mathrm{H} 1$ and $\mathrm{H} 4$, respectively. The median of percentage of fEPSP slope change in hippocampal slices was $101.1,-10.4$ and $50.4 \%$ in groups $\mathrm{H} 0, \mathrm{H} 1$ and $\mathrm{H} 4$, respectively. The increase in both PS amplitudes and fEPSP slope, the 2 indicators of synaptic transmission strength, in hippocampal slices of group $\mathrm{H} 4$ were significantly higher than those in group H1 ( $\mathrm{p}<0.01)$, but no difference was discerned between groups $\mathrm{H} 0$ and $\mathrm{H} 4$ (fig. 3).

\section{Effects of Acute and Repeated Exposure of Mice to \\ Hypoxia on Animal Behavior}

The mice in groups $\mathrm{H} 0$ and $\mathrm{H} 1$ displayed the same behavioral pattern during the test in the modified Morris water maze, whereas an improved performance and very alert and resourceful swimming action were clearly shown in group H4. No significant difference in escape latency was found between groups $\mathrm{H} 0$ and $\mathrm{H} 1$. However, mice in group $\mathrm{H} 4$ took a significantly shorter time to find the submerged platform than those in groups $\mathrm{H} 0$ and $\mathrm{H} 1$, from 1 to 3 days after hypoxic exposure (fig. 4), indicating that the preconditioned animals' ability of learning and memory is improved. There were no differences in swim speed among the 3 groups $(\mathrm{p}>0.05)$.

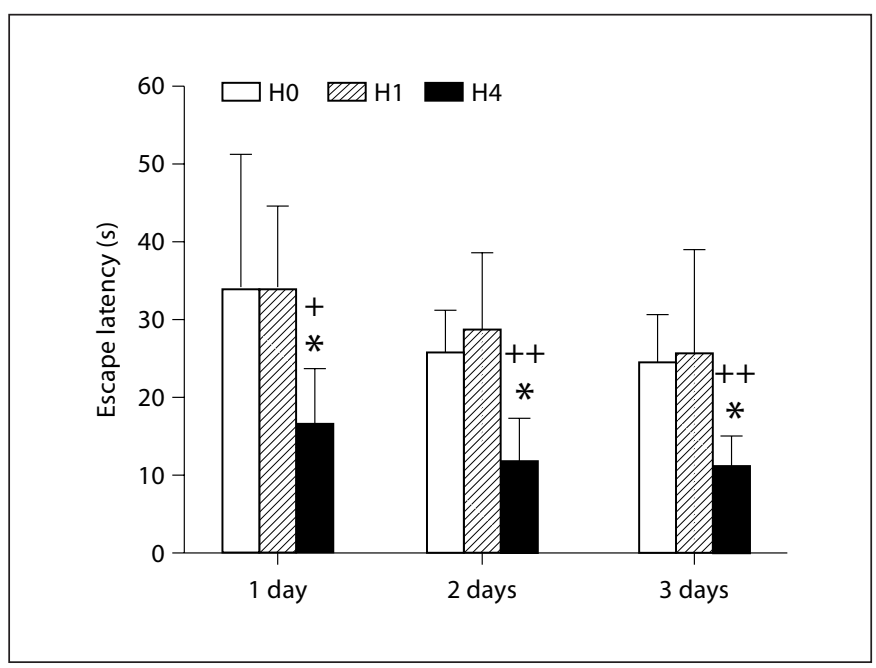

Fig. 4. Effect of repetitive exposure of mice to hypoxia on their escape latency in the Morris water maze task $(n=7) .{ }^{*} \mathrm{p}<0.05$ vs. $\mathrm{H} 0 ;{ }^{+} \mathrm{p}<0.05 ;{ }^{++} \mathrm{p}<0.01$ vs. H1.

\section{Discussion}

In many reports, the neuroprotective function of preconditioning is evaluated predominantly from morphological features of viability of the damaged brain neurons, in particular, the inhibition of neuron apoptosis, or the survival rate of neurons in the striatum, hippocampus and cortex $[2,27,28]$. Although it has been shown that hypoxia may induce extensive injury to susceptible brain neurons, it does not necessarily follow that such injury results in neuronal death, but rather a marked impairment of brain functioning, such as behaviors, stress response, learning and memory [9]. Liu et al. [29, 30] have found that no cell loss in the CA1 and a marked neurogenesis increase in the dentate gyrus appeared in preconditioned animals [29] and that cell proliferation took place in other parts of the hippocampus after ischemia [30]. The regeneration occurring in hippocampus was significantly associated with the spatial cognitive performance in the water maze, although the causality of this correlation has not been unambiguously demonstrated yet [31]. These findings suggest that adult animals might keep a capability of neuron production and tissue remodeling, at least in the hippocampus, to compensate hypoxia/ischemia (H-I)-related injury and to protect the hippocampus form injury by I/HPC. HPC provides a substantial long-term reduction in brain injury in neonatal rats subjected to $\mathrm{H}-\mathrm{I}$. The structural protection was ac- 
companied by significant improvement of sensorimotor as well as spatial/cognitive abilities [10].

In the present study, an enhancement of spatial cognitive ability was shown by the Morris water maze test in mice exposed acutely and repeatedly to hypoxia. Compared with the control group, the spatial cognitive ability of mice exposed to hypoxia once was not changed. Zhang et al. $[24,32]$ have reported that intermittent hypoxia could enhance spatial cognitive ability in young mice but did not affect this ability in adult mice. Others also reported that brief hypobaric hypoxia enhanced animals' cognition. For example, hypobaric hypoxia at an altitude of $7 \mathrm{~km}$ enhanced young rats' spatial orientation [33]. To our knowledge, our study is the first reporting that acute and repeated hypoxic exposure enhances performance of adult mice in a water maze. In contrast with our results, other results suggest that hypoxic exposure impairs, or does not affect, the ability of learning and memory in adult and neonatal animals $[8,9,32]$. This discrepancy could be explained by the differences in the methods for hypoxic exposure and differences in the development stage in which animals were exposed to hypoxia. For instance, when adult rats were exposed to hypobaric hypoxia at the altitudes of 5,500, 5,950 and 6,400 $\mathrm{m}$, the spatial memory was impaired; the neonatal rats' being exposed to severe hypoxia $\left(8 \% \mathrm{O}_{2}\right)$ for $3 \mathrm{~h}$ proved to result in impairment in learning ability; when adult mice were exposed to intermittent hypoxia $(4 \mathrm{~h} /$ day $)$ at the altitudes of 2 or $5 \mathrm{~km}$, the spatial memory was unchanged $[8,9$, 32].

Memory formation depends on the de novo synthesis of proteins and structural modifications at the synaptic level [34]. NCAM is well-known for its involvement in these processes and NCAM is abundantly expressed in the hippocampus. NCAM is a membrane-bound glycoprotein involved in neuronal development, learning/ memory and plastic changes. NCAM knockout mice showed deficiency in learning in the Morris water maze test [35]. Amnesia was induced in rats and chicks injected with NCAM antibody $[36,37]$. In the present study, the total NCAM mRNA level was found to decrease in group $\mathrm{H} 1$ and increase up to the basal level after repeated exposure to hypoxia in group $\mathrm{H} 4$. The changes of NCAM mRNA and protein imply that NCAM may play an important role in neuroprotection during HPC. NCAM is a member of the immunoglobulin superfamily characterized by the immunoglobulin homology module. There are 3 major isoforms of NCAM according to their approximate molecular weight (NCAM-180, NCAM-140 and NCAM-120). NCAM-120 is not detectable in synap- tosomal membranes, whereas NCAM-140 is expressed on both pre- and postsynaptic membranes [38]. By contrast, NCAM-180 is restricted primarily to postsynaptic densities of mature neurons, where it is involved in synaptic functions $[38,39]$, including those regulating sensory gating. New synapse formation occurs in the brain after an H-I event, and this is important for functional recovery after stroke [40]. The change of NCAM-180 might imply that NCAM-180 appears to be a superior material for neurite plasticity, compared to NCAM-140 in HPC. It is suggested that NCAM-180 plays an important role in the recovery from hypoxia, stability of contacts between pre- and postsynaptic membranes and state of synaptic activity after acute and repeated exposure to hypoxia.

It has been shown that the proportion of NCAM containing synapses increases following LTP, a process considered to be an experimental paradigm for memory consolidation [41]. LTP is defined as a long-lasting increase in synaptic effectiveness following high frequency of afferent fiber stimulation and recent experiments have found that the hippocampal LTP played a role in spatial memory $[42,43]$. NCAM knockout mice display deficits in learning, memory and hippocampal LTP [44]. An increase was not only shown in NCAM-180 protein, but also in LTP of the hippocampus slice of the preconditioned mice in the present study.

The amplitude of LTP increased significantly in CA1 of the hippocampus in vivo $10 \mathrm{~min}$ or $70-80$ days after rats were exposed to hypoxia for $15-20 \mathrm{~min}$ at postnatal days 10-11 and the authors presumed that the alteration in excitatory transmission may play a critical role in the events [26]. This LTP, referred to as anoxic LTP, belongs to an N-methyl-D-aspartate (NMDA) receptor-mediated LTP induced by anoxicaglycemic episode (1-3 $\mathrm{min}$ ) in a cultured hippocampal slice [45]. Our previous study has shown that the activity of NMDA receptor is changed after hypoxic exposure [46]. By the mediation of the changed NMDA receptor, $\mathrm{Ca}^{2+}$ influxes into the cell and provides a mechanism for increasing phosphorylated cAMP-responsive element-binding protein further resulting in enhanced LTP [47]. The increase in this protein, a critical event that mediates the initiation of transcription for the synthesis of proteins necessary for long-term memory formation [24] and produces concomitant changes in the underlying synaptic structure and function [48, 49], was also detected in the brain in our model [22]. At the same time, the elevation of postsynaptic calcium concentration is both necessary and sufficient for the induction of hippocampal LTP [50]. Furthermore, calcium-induced 
events might trigger an upregulation of excitability rather than death [51]. So the serial events caused by repeated exposure to hypoxia may produce the changes in LTP and spatial cognitive ability.

In summary, the spatial cognitive ability is proved to be improved in the mice exposed to hypoxia acutely and repeatedly in the present study. The enhancement of this ability might correlate with the changes of gene expression related to HPC and cellular signals triggered by the change of postsynaptic calcium concentration. This find- ing implicates that in addition to increasing tolerance to $\mathrm{H}-\mathrm{I}, \mathrm{HPC}$ is able to improve, but not impair, the ability of spatial learning and memory in adult mice.

\section{Acknowledgments}

This project was supported by the National Natural Science Foundation of China (No. 39670271), the Beijing Natural Science Foundation (No. 7962009) and the Inner Mongolia Educational Research Foundation (No. NJ06011).

\section{References}

1 Murry CE, Jennings RB, Reimer KA: Preconditioning with ischemia: a delay of lethal cell injury in ischemic myocardium. Circulation 1986;74:1124-1136.

2 Kitagawa K, Matsumoto M, Tagaya M, Hata R, Ueda H, Niinobe M, Handa N, Fukunaga R, Kimura K, Mikoshiba K, et al: 'Ischemic tolerance' phenomenon found in the brain. Brain Res 1990;528:21-24.

3 Gidday JM, Fitzgibbons JC, Shah AR, Park TS: Neuroprotection from ischemic brain injury by hypoxic preconditioning in the neonatal rat. Neurosci Lett 1994:168:221-224.

-4 Pérez-Pinzón MA, Mumford PL, Rosenthal $\mathrm{M}$, Sick TJ: Anoxic preconditioning in hippocampal slices: role of adenosine. Neuroscience 1996;75:687-694.

- 5 Emerson MR, Nelson SR, Samson FE, Pazdernik TL: A global hypoxia preconditioning model: neuroprotection against seizure-induced specific gravity changes (edema) and brain damage in rats. Brain Res 1999;4:360-366.

-6 Brucklacher RM, Vannucci RC, Vannucci SJ: Hypoxic preconditioning increases brain glycogen and delays energy depletion from hypoxia-ischemia in the immature rat. Dev Neurosci 2002;24:411-417.

7 Hassen GW, Tian D, Ding D, Bergold PJ: A new model of ischemic preconditioning using young adult hippocampal slice cultures. Brain Res 2004;13:135-143.

-8 Shukitt-Hale B, Stillman MJ, Welch DI, Levy A, Devine JA, Lieberman HR: Hypobaric hypoxia impairs spatial memory in an elevation-dependent fashion. Behav Neural Biol 1994;62:244-252.

-9 Balduini W, De Angelis V, Mazzoni E, Cimino M: Long-lasting behavioral alterations following a hypoxic/ischemic brain injury in neonatal rats. Brain Res 2000;859:318-325.

10 Row BW, Kheirandish L, Cheng Y, Rowell PP, Gozal D: Impaired spatial working memory and altered choline acetyltransferase (chat) immunoreactivity and nicotinic receptor binding in rats exposed to intermittent hypoxia during sleep. Behav Brain Res 2007;177:308-314.
1 Gozal D, Crabtree VM, Sans Capdevila O, Witcher LA, Kheirandish-Gozal L: C-reactive protein, obstructive sleep apnea, and cognitive dysfunction in school-aged children. Am J Respir Crit Care Med 2007;176: 188-193.

12 Zhang SX, Miller JJ, Gozal D, Wang Y: Whole-body hypoxic preconditioning protects mice against acute hypoxia by improving lung function. J Appl Physiol 2004;96: 392-397.

13 Rybnikova E, Vataeva L, Tyulkova E, Gluschenko T, Otellin V, Pelto-Huikko M, Samoilov MO: Mild hypoxia preconditioning prevents impairment of passive avoidance learning and suppression of brain NGFI-A expression induced by severe hypoxia. Behav Brain Res 2005;160:107-114

$14 \mathrm{Lu}$ GW, Cui XY, Zhao BM: Alteration of oxygen consumption and energy metabolism during repetitive exposure of mice to hypoxia. Neurochem Res 1999;24:625-628.

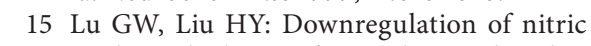
oxide in the brain of mice during their hypoxic preconditioning. J Appl Physiol 2001; 91:1193-1198.

16 Huang P, Qi Z, Bu X, Zhang N, Han S, Fang L, Li J: Neuron-specific phosphorylation of mitogen- and stress-activated protein kinase-1 involved in cerebral hypoxic preconditioning of mice. J Neurosci Res 2007;85: 1279-1287.

17 Jia J, Wang X, Li H, Han S, Zu P, Li J: Activations of nPKCepsilon and ERK1/2 were involved in oxygen-glucose deprivation-induced neuroprotection via NMDA receptors in hippocampal slices of mice. J Neurosurg Anesthesiol 2007;19:18-24.

18 Zhang N, Gao G, Bu X, Han S, Fang L, Li J: Neuron-specific phosphorylation of c-Jun $\mathrm{N}$-terminal kinase increased in the brain of hypoxic preconditioned mice. Neurosci Lett 2007;423:219-224

19 Duan C, Yan F, Song X, Lu GW: Changes of superoxide dismutase, glutathione perioxidase and lipid peroxides in the brain of mice preconditioned by hypoxia. Biol Signals Recept 1999;8:256-260.
20 Long C, Gao Y, Gao G, Han S, Zu P, Fang L, Li J: Decreased phosphorylation and protein expression of ERK1/2 in the brain of hypoxic preconditioned mice. Neuroscience Lett 2006;397:307-312.

$21 \mathrm{Li} \mathrm{J}, \mathrm{Qu} \mathrm{Y,} \mathrm{Zu} \mathrm{P,} \mathrm{Han} \mathrm{S,} \mathrm{Gao} \mathrm{G,} \mathrm{Xu} \mathrm{Q,} \mathrm{Fang} \mathrm{L:}$ Increased isoform-specific membrane translocation of conventional and novel protein kinase $\mathrm{C}$ in human neuroblastoma SH-SY5Y cells following prolonged hypoxia. Brain Res 2006;1093:25-32.

22 Gao Y, Gao G, Long C, Han S, Zu P, Fang L, Li J: Enhanced phosphorylation of cyclic AMP response element binding protein in the brain of mice following repetitive hypoxic exposure. Biochem Biophys Res Commun 2006:340:661-667.

23 Lynch MA: Long-term potentiation and memory. Physiol Rev 2004;84:87-136.

24 Zhang JX, Chen XQ, Du JZ, Chen QM, Zhu CY: Neonatal exposure to intermittent hypoxia enhances mice performance in water maze and 8 -arm radial maze tasks. J Neurobiol 2005;65:72-84.

25 Bergeron M, Gidday JM, Yu AY, Semenza GL, Ferriero DM, Sharp FR: Role of hypoxiainducible factor-1 in hypoxia-induced ischemic tolerance in neonatal rat brain. Ann Neurol 2000;48:285-296.

26 Jensen FE, Wang C, Stafstrom CE, Liu Z, Geary C, Stevens MC: Acute and chronic increases in excitability in rat hippocampal slices after perinatal hypoxia in vivo. J Neurophysiol 1998;79:73-81.

27 Cantagrel S, Krier C, Ducrocq S, Bodard S, Payen V, Laugier J, Guilloteau D, Chalon S: Hypoxic preconditioning reduces apoptosis in a rat model of immature brain hypoxiaischaemia. Neurosci Lett 2003;347:106-110.

28 Kato H, Liu Y, Araki T, Kogure K: Temporal profile of the effects of pretreatment with brief cerebral ischemia on the neuronal damage following secondary ischemic insult in the gerbil: cumulative damage and protective effects. Brain Res 1991;553:238-242. 
29 Liu J, Solway K, Messing RO, Sharp FR: Increased neurogenesis in the dentate gyrus after transient global ischemia in gerbils. J Neurosci 1998;18:7768-7778.

30 Liu J, Solway K, Sharp FR: BrdU uptake into dividing microglia/macrophages occurs in striatum prior to hippocampus following global ischemia in the gerbil. J Cereb Blood Flow Metab 1997;17:S422.

-31 Wurm F, Keiner S, Kunze A, Witte OW, Redecker C: Effects of skilled forelimb training on hippocampal neurogenesis and spatial learning after focal cortical infarcts in the adult rat brain. Stroke 2007;38:2833-2840.

-32 Zhang JX, Lu XJ, Wang XC, Li W, Du JZ: Intermittent hypoxia impairs performance of adult mice in the two-way shuttle box but not in the Morris water maze. J Neurosci Res 2006;84:228-235.

-33 Wittner M, Riha P: Transient hypobaric hypoxia improves spatial orientation in young rats. Physiol Res 2005;54:335-340.

-34 Bailey CH, Bartsch D, Kandel ER: Toward a molecular definition of long-term memory storage. Proc Natl Acad Sci USA 1996;93: 13445-13452.

35 Cremer H, Lange R, Christoph A, Plomann M, Vopper G, Roes J, Brown R, Baldwin S, Kraemer P, Scheff S, et al: Inactivation of the $\mathrm{N}$-CAM gene in mice results in size reduction of the olfactory bulb and deficits in spatial learning. Nature 1994;367:455-459.

-36 Mileusnic R, Rose SP, Lancashire C, Bullock $\mathrm{S}$ : Characterisation of antibodies specific for chick brain neural cell adhesion molecules which cause amnesia for a passive avoidance task. J Neurochem 1995;64:2598-2606.
Arami S, Jucker M, Schachner M, Welzl H: The effect of continuous intraventricular infusion of L1 and NCAM antibodies on spatial learning in rats. Behav Brain Res 1996;81: 81-87.

38 Persohn E, Pollerberg GE, Schachner M: Immunoelectron-microscopic localization of the $180 \mathrm{kD}$ component of the neural cell adhesion molecule N-CAM in postsynaptic membranes. J Comp Neurol 1989;288:92100.

39 Dityatev A, Dityateva G, Schachner M: Synaptic strength as a function of post- versus presynaptic expression of the neural cell adhesion molecule NCAM. Neuron 2000;26: 207-217.

40 Villablanca JR, Hovda DA: Developmental neuroplasticity in a model of cerebral hemispherectomy and stroke. Neuroscience 2000; 95:625-637.

41 Schuster T, Krug M, Hassan H, Schachner M: Increase in proportion of hippocampal spine synapses expressing neural cell adhesion molecule NCAM180 following long-term potentiation. J Neurobiol 1998;37:359-372.

-42 Whitlock JR, Heynen AJ, Shuler MG, Bear MF: Learning induces long-term potentiation in the hippocampus. Science 2006;313: 1093-1097.

43 Pastalkova E, Serrano P, Pinkhasova D, Wallace E, Fenton AA, Sacktor TC: Storage of spatial information by the maintenance mechanism of LTP. Science 2006;313:11411144.
44 Bukalo O, Fentrop N, Lee AY, Salmen B, Law JW, Wotjak CT, Schweizer M, Dityatev A, Schachner M: Conditional ablation of the neural cell adhesion molecule reduces precision of spatial learning, long-term potentiation, and depression in the CA1 subfield of mouse hippocampus. J Neurosci 2004;24: 1565-1577.

45 Crepel V, Hammond C, Krnjevic K, Chinestra P, Ben-Ari Y: Anoxia-induced LTP of isolated NMDA receptor-mediated synaptic responses. J Neurophysiol 1993;69:1774-1778.

46 Xie JH, Lu GW, Hou YZ: Role of excitatory amino acids in hypoxic preconditioning. Biol Signals Recept 1999;8:267-274.

-47 Tsubokawa H, Oguro K, Robinson HP, Masuzawa T, Kirino T, Kawai N: Abnormal Ca ${ }^{2+}$ homeostasis before cell death revealed by whole cell recording of ischemic CA1 hippocampal neurons. Neuroscience 1992;49:807817.

48 Kandel ER: The molecular biology of memory storage: a dialogue between genes and synapses. Science 2001;294:1030-1038.

49 Tully T, Bourtchouladze R, Scott R, Tallman J: Targeting the CREB pathway for memory enhancers. Nat Rev Drug Discov 2003;2. 267-277.

50 Bliss TV, Collingridge GL: A synaptic model of memory: long-term potentiation in the hippocampus. Nature 1993;361:31-39.

51 Ghosh A, Greenberg ME: Calcium signaling in neurons: molecular mechanisms and cellular consequences. Science 1995;268:239247. 